4. Tá Đức Chung (2019), Đánh giá kết quả chăm sóc người bệnh chấn thương sau phẫu thuật tại bênh viên trung ương quân đội 108, Luận văn Thạc sỹ Điều dưỡng, Trường Đaai học Thăng Long.

5. Nguyễn Gia Dũng (2019), Đ̇ặc điểm, chăm sóc người bệnh phẫu thuật gãy xương chi dưới và các yếu tố liền quan đến chăm sóc tại khoa ngoại bệnh viện Đức Giang, Luận văn Thạc sỹ Điều dưỡng, Trường Đại học Thăng Long.

6. Đào Đức Hạnh (2015), Thức trang công tác chăm sóc điều dưỡng người bệnh cần chăm sóc cấp I tai viện chấn thương chỉnh hình, bệnh viên trung ương quân đội 108 năm 2015, Luận vằn Thạc sỹ quản lý bệnh viện, Đại học Y tế công cộng.

\title{
NHẬN XÉT ĐĂC ĐIỂM SIÊU ÂM VÀ GIẢI PHẪU BÊNH CỦA BƯớU NHÂN TUYẾN GIÁP TẠI BỆNH VIỆN ĐA KHOA TỈNH THÁI BİNH
}

\section{TÓM TẮT.}

Muc tiêu: Nhân xét đặc điểm siêu âm và giải phẫu buệnh của bướu nhân tưyến giáp tại bệnh viện đa khoa tỉnh Thái Bình. Phương pháp: nghiển cứu tiến cứu mô tả cắt ngang. Nghiên cứu được tiến hành trên 176 bệnh nhân có bướu nhân tuyến giáp được chọc hút kim nhỏ dưới hướng dẫn của siêu âm tại bệnh viện đa khoa tỉnh Thái Bình. Kết quả: Kích thước trung bình của các nhân u được chọc hút là 10,5 \pm $7,2 \mathrm{~mm}$. Các bướu nhân có bờ đều, ranh giới rõ chiếm tỷ lệ cao $(85,2 \%)$, bờ không đều chiếm tỷ lệ thấp. Phần lớn các nhân giáp là hốn hợp âm $(51,7 \%)$, sau đó là giảm âm (32,4\%), các nhân tăng âm hoặc đồng âm chiếm tỷ lệ thấp. Các nhân giáp không có hiện tượng vôi hóa chiếm tỷ lệ $68,8 \%$, các nhân có vi vôi hóa chiếm tỷ lệ $9,0 \%$. Chẩn đoán mô bệnh học: bướu giáp keo lành chiếm tỷ lệ 70,9\%, UTBM thể nhú $19,4 \%$, u tuyến nang $9,7 \%$. Các nhân giáp ác tính thường có kích thước nhỏ $<10 \mathrm{~mm}(66,7 \%)$, là nhân giảm âm $(66,6 \%)$ và có vi vôi hóa $(66,7 \%)$.

\section{SUMMARY}

\section{A REVIEW THE CHARATERISTICS OF UNTRASOUND AND PATHOLOGY OF THE THYROID NODULES AT THAIBINH GENERAL HOSPITAL}

Objective: To review the characteristics of ultrasound and pathology of the thyroid nodules at Thai Binh General Hospital. Methods: cross-sectional descriptive research. The study was conducted on 176 patients with thyroid neoplasm using FNA with ultrasound guidance at Thai Binh General Hospital. Result: The average size of the neoplasms was 10.5 $\pm 7.2 \mathrm{~mm}$. Neoplasms have equal and clear border accounts for a high rate (85.2\%). Most of the turmors is mixed echo $(51.7 \%)$, followed by hypoechoic $(32.4 \%)$. The turmors without calcification phenomenon were $68.8 \%$ and microcalcifications were 9.0\%. Diagnosis of histopathology: goiter: $70.9 \%$, adenoma $9.7 \%$, papillary carcinoma $19.4 \%$. Malignant

${ }^{1}$ Trường Đại hoc Y Dược Thái Bình

Chịu trách nhiệm chính: Trần Mạnh Hà

Email: manhha.tbump@gmail.com

Ngày nhận bài: 13.8.2021

Ngày phản biên khoa học: 4.10 .2021

Ngày duyệt bài: 15.10.2021

\section{Trần Mạnh Hà ${ }^{1}$, Nguyễn Thị Thanh Hà ${ }^{1}$}

thyroid nodules usually have a small size $<10 \mathrm{~mm}$ $(66.7 \%)$, are hypoechoic $(66.6 \%)$ and have microcalcification (66.7\%).

\section{I. ĐẶT VẤN ĐỀ}

Tuyến giáp là một tuyến nội tiết quan trọng của cơ thể, có vai trò điều hòa hoạt động của các cơ quan, thúc đẩy sự phát triển của tế bào và kiểm soát sử dụng năng lượng. Bệnh lí tuyến giáp rất đa dạng nhưng biểu hiện lâm sàng muộn, triệu chứng không rầm rộ nên dễ bị bỏ sót. Hơn nữa, một số tổn thương có kích thước nhỏ hoăc nằm ở vị trí khó tiếp cận nên ít nhiêu gây khó khăn cho chẩn đoán. Hiện nay có rất nhiều loại xét nghiệm được sử dụng trong chẩn đoán bướu nhân tuyến giáp, trong đó siêu âm và chọc hút kim nhỏ được coi là những phương tiện chẩn đoán rất hiệu quả giúp phát hiện sớm và tìm hiểu bản chất của bướu giáp. Việc phát hiện các nhân giáp có đường kính $<1 \mathrm{~cm}$ hoặc ở vị trí sâu trên lâm sàng là rất khó khăn nhưng nếu áp dụng siêu âm vào chẩn đoán thì tỉ lệ phát hiện bướu nhân tuyến giáp tăng lên khoảng 10 lần so với khám lâm sàng, [1],[2],[3]. Tuy nhiên, siêu âm vẫn chưa đủ để nói lên tổn thương đó là ác hay lành tính. Chọc hút kim nhỏ là kỹ thuật đơn giản nhưng rất giá trị trong việc xác định bản chất một nhân tuyến giáp. Tuy nhiên, chọc hút kim nhỏ có thể bỏ sót các tổn thương nhỏ, đa thương tổn hoặc ở vị trí khó tiếp cận. Việc kết hợp siêu âm và chọc hút kim nhỏ sẽ bổ sung cho nhau, phần nào tránh được các hạn chế của mỗi phương pháp. Vì vậy, chúng tôi tiển hành nghiên cứu này với mục tiêu: Nhận xét đặc điểm siêu âm và giải phẫu bệnh của bướu nhẩn tuyến giáp tại bệnh viện đa khoa tỉnh Thái Bình năm 2019.

\section{II. ĐỐI TƯỢNG VÀ PHƯƠNG PHÁP NGHIÊN CỨU \\ 1. Đối tượng nghiên cứu}

2.1.1. Đối tượng nghiên cứu. Nghiên cứu gồm 176 bệnh nhân có bướu nhân tuyến giáp được khám và điều trị tại các khoa Nội tiết, Ung 
bướu bệnh viện đa khoa tỉnh Thái Bình trong khoảng thời gian từ tháng 1/2019 - 6/2019.

- Tiêu chuấn chọn bênh nhân:

+ Được chẩn đoán có bướu nhân tuyến giáp

+ Có kết quả siêu âm tuyến giáp và vùng cổ

+ Được chọc hút kim nhỏ dưới hướng dẫn của siêu âm và làm xét nghiệm tế bào học

\section{Phương pháp nghiên cứu}

2.1. Thiết kế nghiên cứu. Nghiên cứu được tiến hành theo phương pháp tiến cứu mô tả cắt ngang.

2.2. Cỡ mẫu và chon mấu. Chúng tôi chọn mẫu thuân tiện, lấy tất cả bệnh nhân có đủ tiểu chuẩn để đưa vào nghiên cứu. Số bệnh nhân trong nghiên cứu là 176.

\subsection{Các bước tiến hành nghiên cứu}

\subsubsection{Thu thập thông tin}

- Thu thâp các thông tin chung: tuổi, giới

- Đặc điểm bướu nhân trên siêu âm: số lượng, vị trí, kích thước, tính chất phản âm, vôi hóa...

- Kết quả tế bào học chọc hút kim nhỏ dưới hướng dẫn của siêu âm và kết quả mô bệnh học

2.3.2. Kỹ thuật chọc hút kim nhỏ dưới hướng dẫn siêu âm

- Sát trùng vùng tuyến giáp chọc hút đã được xác định trên lâm sàng và trên siêu âm.

- Xác định lại vị trí u giáp trên siêu âm, đường vào $\mathrm{u}$ gần nhất và dễ nhất.

- Cố định vị trí cần chọc, tay cầm kim có gắn bơm tiêm đâm qua da vào tổn thương và theo dõi đường đi của kim chọc trên màn hình siêu âm.

- Hút dưới áp lực âm để dịch chọc vào trong lòng kim. Cố định mũi kim trong khi hút để tránh chảy máu và làm đau bệnh nhân.

- Có thể xoay mũi kim theo nhiều hướng hoặc chọc hút nhiều vị trí trên tổn thương để lấy đủ bệnh phẩm (nếu tổn thương $>1,5 \mathrm{~cm}$ ).

- Rút nhanh kim qua da (trước khi rút mũi kim cần giải phóng áp lực âm).

- Sát trùng lại vị trí đã chọc, băng ép (nếu cần).

2.3.3. Kỹ thuật làm tiêu bản tế bào học và mô bệnh học thường quy

Kỹ thuật làm tiêu bản tế bào học

- Tháo kim ra khỏi bơm tiêm. tiêm.

- Kéo xilanh xuống để lấy không khí vào bơm

- Lắp kim vào bơm tiêm.

- Nhanh chóng phụt dịch chọc ra lam kính đã ghi sẵn mã số bệnh nhân.

- Dàn đều bềnh phẩm.

- Để khô và cố định tiêu bản bằng cồn - ete tỷ lệ $1: 1$.

- Nhuộm Hematoxylin - Eosin hoặc Giem sa.

- Nhận định tổn thương trên kính hiển vi quang học. Phân loại tổn thương tế bào học theo

\section{Bethesda.}

Kỹ thuật làm tiêu bản mô bệnh học

- Tất cả các bệnh phẩm được cố định bằng dung dịch Formol 10\% trong 12 giờ.

- Chuyển bệnh phẩm theo chu trình kỹ thuật thường quy qua các chặng hóa chất cồn toluene - paraffin.

- Đúc nến.

- Cắt mảnh hàng loạt trên máy Microtom với độ dày $3 \mu \mathrm{m}$.

- Nhuộm tiêu bản bằng phương pháp Hematoxylin - Eosin thường quy.

- Đọc tiêu bản: các tiêu bản được phân tích dưới kính hiển vi quang học với độ phóng đại 50, 100, 400 lần. Xác định tổn thương và phân loại mô bệnh học theo WHO. Các tiêu bản cắt nhuộm xấu hoặc mờ nhạt được cắt nhuộm và đánh giá lại.

2.4. Các chỉ số, biến số nghiên cứu và tiêu chuẩn đánh giá

- Các chỉ số chung: tuổi, giới

- Đặc điểm bướu nhân trên siêu âm: vị trí, số lượng, kích thước, bờ và giới hạn u, tính chất phản âm, vôi hóa, độ TIRADS, hạch vùng.

- Đặc điểm tế bào học: đọc và phân loại tổn thương theo Bethesda. Đặc điểm mô bệnh học: đọc và phân loại tổn thương theo WHO.

2.5. Xử lý số liệu. Các số liệu được xử lý bằng phần mềm thống kê SPSS 22.0.

\section{KẾT QUẢ NGHIÊN CỨU}

Bảng 3.1. Vị trí, số lượng, kích thước, bờ và giới han bướu nhân trên siêu âm

\begin{tabular}{|c|c|c|c|c|}
\hline \multicolumn{2}{|c|}{ Đăc điểm siêu âm } & Số BN & Tỷ lê \% & $\mathbf{P}$ \\
\hline \multirow{4}{*}{ Vị trí } & Thùy $\mathrm{P}$ & 85 & 48,4 & $p>$ \\
\hline & Thùy $\mathrm{T}$ & 65 & 36,9 & 0,05 \\
\hline & Eo & 2 & 1,1 & \\
\hline & Hai bên & 24 & 13,6 & \\
\hline \multicolumn{2}{|c|}{ Tổng số } & 176 & 100,0 & \\
\hline \multirow{2}{*}{ Số lượng } & Đơn nhân & 130 & 73,9 & \\
\hline & Đa nhân & 46 & 26,1 & \\
\hline \multicolumn{2}{|c|}{ Tổng số } & 176 & 100,0 & \\
\hline \multirow{3}{*}{$\begin{array}{l}\text { Kích } \\
\text { thước }\end{array}$} & $<10 \mathrm{~mm}$ & 133 & 75,6 & \\
\hline & $10-20 \mathrm{~mm}$ & 37 & 21,0 & \\
\hline & $>20 \mathrm{~mm}$ & 6 & 3,4 & \\
\hline \multicolumn{2}{|c|}{ Tống số } & 176 & 100,0 & \\
\hline \multirow{3}{*}{\begin{tabular}{|c|}
$\begin{array}{c}\text { Bờ và giới } \\
\text { hạn }\end{array}$ \\
Tổn
\end{tabular}} & Đều, rõ & 150 & 85,2 & \\
\hline & Không đều & 26 & 14,8 & \\
\hline & g số & 176 & 100,0 & \\
\hline
\end{tabular}

Nhân xét: - Vị trí: các nhân giáp ở thùy phải chiếm tỷ lệ cao nhất $(48,4 \%)$, thùy trái chiếm $36,9 \%$, nhiều nhân ở cả 2 thùy tuyến chiếm $13,6 \%$, các khối u ở vùng eo tuyến giáp chiếm tỷ lệ rất thấp $(1,1 \%)$.

- Số lượng: phần lớn bệnh nhân chỉ có một 
nhân u đơn độc (chiếm 73,9\%), các bệnh nhân có nhiều nhân chiếm $26,1 \%$.

- Kích thước: đa số các nhân u được chọc hút có kích thước nhỏ < 10mm (chiếm 75,6\%), các nhân u có kích thước $>20 \mathrm{~mm}$ chiếm tỷ lệ thấp $(3,4 \%)$. Kích thước nhỏ nhất là $3 \mathrm{~mm}$, lớn nhất là $35 \mathrm{~mm}$, kích thước trung bình của các nhân u được chọc hút là 10,5 \pm 7,2mm.

- Bờ và giới hạn nhân u: các nhân u có bờ đều, ranh giới rõ chiếm tỷ lệ cao $(85,2 \%)$, bờ không đều chiếm tỷ lệ thấp $(14,8 \%)$.

Bảng 3.2. Tính chất phản âm, vôi hóa của bướu nhân tuyến giáp trên siêu âm

\begin{tabular}{|c|c|c|c|}
\hline \multicolumn{2}{|c|}{ Đặc điếm siêu âm } & Số BN & Tỷ lệ \% \\
\hline \multirow{4}{*}{$\begin{array}{l}\text { Tính chất } \\
\text { phản âm }\end{array}$} & Hôn hợp âm & 91 & 51,7 \\
\hline & Giảm âm & 57 & 32,4 \\
\hline & Tăng âm & 18 & 10,2 \\
\hline & Đồng âm & 10 & 5,7 \\
\hline \multicolumn{2}{|c|}{ Tống số } & 176 & 100,0 \\
\hline \multirow{3}{*}{$\begin{array}{l}\text { Dấu hiếu } \\
\text { vôi hóa }\end{array}$} & Không & 121 & 68,8 \\
\hline & Vôi hóa thô & 39 & 22,2 \\
\hline & Vi vôi hóa & 16 & 9,0 \\
\hline \multicolumn{2}{|c|}{ Tổng số } & 176 & 100,0 \\
\hline
\end{tabular}

Nhận xét: - Tính chất phản âm: đa số các nhân giáp trong nghiên cứu là hỗn hợp âm $(51,7 \%)$, sau đó là giảm âm $(32,4 \%)$, các nhân tăng âm hoặc đồng âm chiếm tỷ lệ thấp.

- Dấu hiệu vôi hóa: các nhân giáp không có hiện tượng vôi hóa chiếm đa số $(68,8 \%)$, các nhân có vi vôi hóa chiếm tỷ lệ thấp nhất $(9,0 \%)$.
Bảng 3.3. Kêt quả chẩn đoán tế bào học \begin{tabular}{|l|c|c|}
\hline Chấn đoán tế bào học & Số BN & Tỷ lệ \% \\
\hline
\end{tabular}

\begin{tabular}{|c|c|c|c|}
\hline \multirow{2}{*}{ Lành tính } & Bướu giáp keo & 148 & 84,0 \\
\cline { 2 - 4 } & U tuyễn nang & 20 & 11,4 \\
\hline \multirow{2}{*}{ Nghi ngờ } & Quá sản tế bào & 1 & 0,6 \\
\cline { 2 - 4 } & $\begin{array}{c}\text { Tế bào không } \\
\text { điển hình }\end{array}$ & 1 & 0,6 \\
\hline Ȧc tính & UTBM nhú & 6 & 3,4 \\
\hline \multicolumn{2}{|c|}{ Tống số } & $\mathbf{1 7 6}$ & $\mathbf{1 0 0 , 0}$ \\
\hline
\end{tabular}

Nhận xét: kết quả chẩn đoán tế bào học cho thây đa số các bướu nhân là lành tính $(95,4 \%)$, có $3,4 \%$ các trường hợp được chẩn đoán là ung thư biểu mô tuyến giáp thể nhú, còn lại là nghi ngờ $(1,2 \%)$.

Bảng 3.4. Kêt quả chẩn đoán mô bệnh học

\begin{tabular}{|c|c|c|c|c|}
\hline \multicolumn{2}{|c|}{$\begin{array}{c}\text { Chấn đoán } \\
\text { mô bệnh học }\end{array}$} & Số BN & \multicolumn{2}{|c|}{ Tỷ lệ \% } \\
\hline \multirow{2}{*}{ Khóng } & $\begin{array}{c}\text { U tuyến nang } \\
\text { lành tính }\end{array}$ & 3 & 9,7 & 1,7 \\
\cline { 2 - 5 } & $\begin{array}{c}\text { Bướu giáp keo } \\
\text { lành tính }\end{array}$ & 22 & 70,9 & 12,5 \\
\cline { 2 - 5 } & UTBM thến nhú & 6 & 19,4 & 3,4 \\
\hline \multicolumn{2}{|c|}{ Tống số } & $\mathbf{1 7 6}$ & \multicolumn{2}{|c|}{$\mathbf{1 0 0 , 0}$} \\
\hline
\end{tabular}

Nhận xét: trong số các bệnh nhân nghiên cứu chỉ có $31 / 176$ bệnh nhân $(17,6 \%)$ được tiến hành phẫu thuật cắt bỏ bướu nhân và làm xét nghiệm mô bệnh học sau mổ, trong đó UTBM thể nhú chiếm tỷ lệ $3,4 \%$, bướu giáp keo lành chiếm $12,5 \%$, u tuyến nang ít gặp nhất $(1,7 \%)$.

Bảng 3.5. Đôî chiêuu kích thước bướu nhân trên siêu âm với chẩn đoán mô bệnh học

\begin{tabular}{|c|c|c|c|c|c|c|}
\hline \multirow{2}{*}{ Món bệnh hộ } & \multicolumn{2}{c|}{ Lành tính } & \multicolumn{2}{c|}{ Ac tính } & \multicolumn{2}{c|}{ Tống số } \\
\cline { 2 - 7 } Kî́c & Số BN & $\mathbf{\%}$ & Số BN & $\mathbf{\%}$ & Số BN & $\mathbf{\%}$ \\
\hline$<10 \mathrm{~mm}$ & 9 & 36,0 & 4 & 66,7 & $\mathbf{1 3}$ & $\mathbf{4 1 , 9}$ \\
\hline $10-20 \mathrm{~mm}$ & 14 & 56,0 & 2 & 33,3 & $\mathbf{1 6}$ & $\mathbf{5 1 , 6}$ \\
\hline$>20 \mathrm{~mm}$ & 2 & 8,0 & 0 & 0,0 & $\mathbf{2}$ & $\mathbf{6 , 5}$ \\
\hline Tống số & $\mathbf{2 5}$ & $\mathbf{1 0 0 , 0}$ & $\mathbf{6}$ & $\mathbf{1 0 0 , 0}$ & $\mathbf{3 1}$ & $\mathbf{1 0 0 , 0}$ \\
\hline
\end{tabular}

Nhận xét: trong số các bướu nhân có chẩn đoán mô bênh học là ác tính thì có 4 trường hợp có kích thước < 10mm (chiếm 66,7\%), 2 trường hợp có kích thước từ $10-20 \mathrm{~mm}(33,3 \%)$, không có trường hợp nào kích thước $>20 \mathrm{~mm}$.

Bảng 3.6. Đối chiếu đặc điểm giới hạn của bướu nhân trên siêu âm với chẩn đoán mô bệnh học

\begin{tabular}{|c|c|c|c|c|c|c|c|}
\hline MBH & Lành & ính & & & & & \\
\hline Bờ và giới han & Số BN & $\%$ & Số BN & $\%$ & Số BN & $\%$ & $\mathbf{p}$ \\
\hline Đều, rõ & 24 & 96,0 & 3 & 50,0 & 27 & 87,1 & \\
\hline Không đều & 1 & 4,0 & 3 & 50,0 & 4 & 12,9 & ,05 \\
\hline Tống số & 25 & 100,0 & 6 & 100,0 & 31 & 100,0 & \\
\hline
\end{tabular}

Nhận xét: đa số các bướu nhân lành tính có bờ đều, ranh giới rõ (chiếm 96,0\%).

Bảng 3.7. Đối chiếu tính chất phản âm của bướu nhân trên siêu âm với chẩn đoán mô bệnh học

\begin{tabular}{|c|c|c|c|c|c|c|}
\hline \multirow{2}{*}{ T/c phản âm } & \multicolumn{2}{|c|}{ Lành tính } & \multicolumn{2}{c|}{ Ac tính } & \multicolumn{2}{c|}{ Tống số } \\
\cline { 2 - 7 } & Số BN & $\mathbf{\%}$ & Số BN & $\mathbf{\%}$ & Số BN & $\mathbf{\%}$ \\
\hline Hôn hợp âm & 15 & 60,0 & 1 & 16,7 & $\mathbf{1 6}$ & $\mathbf{5 1 , 6}$ \\
\hline Giảm âm & 5 & 20,0 & 4 & 66,6 & $\mathbf{9}$ & $\mathbf{2 9 , 0}$ \\
\hline
\end{tabular}




\begin{tabular}{|c|c|c|c|c|c|c|}
\hline Tăng âm & 4 & 16,0 & 1 & 16,7 & $\mathbf{5}$ & $\mathbf{1 6 , 1}$ \\
\hline Đồng âm & 1 & 4,0 & 0 & 0,0 & $\mathbf{1}$ & $\mathbf{3}, \mathbf{2}$ \\
\hline Tống số & $\mathbf{2 5}$ & $\mathbf{1 0 0 , 0}$ & $\mathbf{6}$ & $\mathbf{1 0 0 , 0}$ & $\mathbf{3 1}$ & $\mathbf{1 0 0 , 0}$ \\
\hline
\end{tabular}

Nhận xét: - Trong nhóm lành tính, đa số các trường hợp là hỗn hợp âm (chiếm $60,0 \%), 20,0 \%$ là giảm âm, $16,0 \%$ là tăng âm, chỉ có 1 trường hợp nhân giáp đồng âm, chiếm tỷ lệ thấp $(4,0 \%)$.

- Trong nhóm ác tính: 66,6\% trường hợp là giảm âm, 16,7\% các nhân giáp hỗn hợp âm hoặc tăng âm.

Bảng 3.8. Đôii chiếu các dấu hiệu vôi hóa trên siêu âm với chẩn đoán mô bệnh học

\begin{tabular}{|c|c|c|c|c|c|c|}
\hline \multirow{2}{*}{$\begin{array}{c}\text { MBH } \\
\text { Vôi hóa }\end{array}$} & \multicolumn{2}{|c|}{ Lành tính } & \multicolumn{2}{c|}{ Ác tính } & \multicolumn{2}{c|}{ Tống số } \\
\cline { 2 - 7 } & Số BN & $\mathbf{\%}$ & Số BN & $\mathbf{\%}$ & Số BN & $\mathbf{\%}$ \\
\hline Không & 19 & 76,0 & 2 & 33,3 & $\mathbf{2 1}$ & $\mathbf{6 7 , 7}$ \\
\hline Vôi hóa thô & 3 & 12,0 & 0 & 0,0 & $\mathbf{3}$ & $\mathbf{9 , 7}$ \\
\hline Vi vôi hóa & 3 & 12,0 & 4 & 66,7 & $\mathbf{7}$ & $\mathbf{2 2 , 6}$ \\
\hline Tống số & $\mathbf{2 5}$ & $\mathbf{1 0 0 , 0}$ & $\mathbf{6}$ & $\mathbf{1 0 0 , 0}$ & $\mathbf{3 1}$ & $\mathbf{1 0 0 , 0}$ \\
\hline $\mathbf{p}$ & \multicolumn{2}{|c|}{$\mathbf{p}<\mathbf{0 , 0 5}$} & \multicolumn{2}{|c|}{$\mathbf{0}<\mathbf{0 , 0 5}$} & \multicolumn{3}{l}{} \\
\hline
\end{tabular}

Nhận xét: trong nhóm lành tính có 19 trường hợp không có vôi hóa (chiếm 76,0\%), vôi hóa thô và vi vổi hóa (chiếm 12,0\%). Trong nhóm ác tính có tới 4 trường hợp có vi vôi hóa (chiếm $66,7 \%$ ).

\section{BÀN LUẬN}

4.1. Đặc điểm của nhân giáp trên siêu âm. Nghiên cứu về vị trí nhân giáp trong bảng 3.1 cho thấy: vị trí ở thùy phải chiếm tỷ lệ cao nhất $(48,4 \%)$, sau đó là thùy trái $(36,9 \%)$, số bệnh nhân có nhiều nhân xuất hiện ở cả 2 thùy tuyến chiếm $13,6 \%$, các khối u ở vùng eo tuyến giáp chiếm tỷ lệ rất thấp. Không có sự khác biệt về vị trí bướu nhân tuyến giáp ở thùy phải so với thùy trái $(p>0,05)$. Kết quả nghiên cứu của chúng tôi cũng phù hợp với các nghiên cứu được công bố trước đây. Theo kết quả nghiên cứu của Nguyễn Thị Hồng tỷ lệ u tuyến giáp gặp ở thùy trái và phải là tương đương nhau $(46,6 \%$ ở thùy phải và $43,2 \%$ ở thùy trái, $p>0,05)$. U nằm ở eo tuyến ít gặp hơn. Một số trường hợp u có ở cả hai thùy nhưng bệnh nhân không rõ̃ bên nào có trước, ở những bệnh nhân này có thể do u phát triển trên nền một viêm giáp Hashimoto hoặc bệnh lý bướu giáp đa nhân [4].

Về số lượng u: phần lớn bệnh nhân chỉ có một nhân u đơn độc (chiếm 73,9\%), các bệnh nhân có nhiều nhân chiếm $26,1 \%$. Kết quả này không khác nhiều so với nghiên cứu của Chu Thị Giang [5] (bướu đơn nhân $65,6 \%$ và bướu đa nhân 34,4\%), của Nguyễn Thị Hoa Hồng [6] (bướu đơn nhân $58,2 \%$ và bướu đa nhân $41,8 \%$ ).

Trong nghiên cứu này, chúng tôi chỉ tiến hành chọc hút các nhân giáp có độ TIRADS $3,4,5$. Về kích thước các nhân u được chọc hút: đa số các trường hợp nhân u có kích thước nhỏ $<10 \mathrm{~mm}$ (chiếm 75,6\%), các nhân có kích thước $>20 \mathrm{~mm}$ chiếm tỳ lệ thấp $(3,4 \%)$. Kích thước nhỏ nhất là $3 \mathrm{~mm}$, lớn nhất là $35 \mathrm{~mm}$, kích thước trung bình của các nhân u được chọc hút là 10,5 $\pm 7,2 \mathrm{~mm}$. Kích thước trung bình của nhân u trong nghiên cứu này lớn hơn so với nghiên cứu của Nguyễn Thị Hồng [4] $(9,5 \pm 5,3 \mathrm{~mm})$ nhưng nhỏ hơn với nghiên cứu của các tác giả Nguyễn Thị Hoa Hồng [6], Nguyễn Thị Minh Thức [7]. Có thể lý giải điều này do bướu nhân tuyến giáp ngày càng được phát hiện ở giai đoạn sớm và tốt hơn do sự phát triển của siêu âm và chọc hút kim nhỏ, hơn nữa kiến thức của người dân về chăm sóc và bảo vệ sức khỏe cũng tốt hơn, tỷ lệ khám bênh định kỳ tăng lên rõ rệt. Số bệnh nhân tình cờ phát hiện ra khối u tuyến giáp không phải là hiếm. Trên lâm sàng rất khó phát hiện những nhân giáp có kích thước < $1 \mathrm{~cm}$, thồng thường chỉ phát hiện được các nhân giáp có kích thước $>1 \mathrm{~cm}$ và nằm ở vị trí dễ phát hiện, $50 \%$ nhân tuyến giáp được phát hiện trên siểu âm đã bị bỏ sót qua thăm khám lâm sàng, ngay cả những nhân có kích thước $>2 \mathrm{~cm}$ đôi khi cũng có thể bị bỏ sót. Vì vậy, nhiều tác giả khuyến cáo nên đưa siêu âm tuyến giáp vào các xét nghiệm thường quy nhất là ở các đối tượng có nguy cơ cao.

Vôi hóa là một đặc điểm hay gặp trong các bướu tuyến giáp và được chia thành nhiêu loại: vi vôi hóa, vôi hóa thô hoặc vôi hóa viền kiểu vỏ trứng. Nhân ác tính gặp tỷ lệ vôi hóa nhiều hơn. Nhiều nghiên cứu đã chứng minh sự hiện diện của vôi hóa trong nhân giáp làm tăng nguy cơ ác tính. Kết quả nghiên cứu của chúng tôi cho thấy: các nhân giáp không có hiện tượng vôi hóa chiếm tỷ lệ cao $(68,8 \%)$, các nhân có vi vôi hóa chiếm tỷ lệ thấp nhất $(9,0 \%)$.

4.2. Đặc điểm giải phẫu bệnh. Bảng 3.3 nghiên cứu về kết quả chẩn đoán tế bào học cho thấy đa số các bướu nhân là lành tính $(95,4 \%)$, nghi ngờ $(1,2 \%)$, ung thư biểu mô tuyến giáp 
thể nhú 3,4\%. Kết quả của chúng tôi cũng phù hợp với các nghiên cứu trước đây. Theo Chu Thị Giang [5] kết quả chọc hút kim nhỏ dưới hướng dẫn của siêu âm như sau: tỷ lệ ác tính là 5,5\%, nghi ngờ ác tính là 3,4\%, lành tính là $91,1 \%$. Nghiên cứu của Nguyến Thị Hoa Hồng [6] cho kết quả $60 \%$ lành tính, chỉ có $5,5 \%$ ác tính.

Hình ảnh tế bào học trên phiến đồ trong một số bệnh lý tuyến giáp:

- Bướu giáp keo:

+ Chất keo đồng nhất, có thể thấy tinh thể hình que, hình thoi.

+ Biểu mô tuyến nghèo nàn, thưa thớt, nhân nhỏ, đồng dạng.

- Ung thư biểu mô thể nhú: hầu hết trên phiến đồ chọc hút kim nhỏ của UTBM tuyến giáp chúng tôi thường gặp các hình thái tổn thương sau:

+ Tăng sinh tế bào rõ rệt: mật độ tế bào dày đặc trên mối phiến đồ. Thường nhiều hơn trong các u lành, bướu giáp đơn thuân, kể cả typ quá sản biểu mô.

+ Tế bào $u$ thể hiện tính chất bất thường, đa hình ở các mức độ khác nhau: tế bào tăng kích thước, to nhỏ khồng đều, nhân tăng sắc, chất nhiễm sắc thô, vón cục. Đôi khi có nhiều hạt nhân to, nổi rõ̂, một số có nhân chia điển hình hoặc không điển hình.

+ Phiến đồ thường ít hoặc không có chất keo

+ Tổn thương kèm theo: xen kẽ tế bào ung thư còn thấy hồng cầu ít nhiêuu thoái hóa, tế bào lympho, bạch cầu đa nhân trung tính.

Trong số 176 bệnh nhân tham gia nghiên cứu chỉ có $31 / 176$ bệnh nhân (chiếm 17,6\%) được tiến hành phẫu thuật cắt bỏ nhân u, kết quả chẩn đoán mô bệnh học trong bảng 3.4 như sau: bướu giáp keo lành chiếm tỷ lệ cao nhất $(70,9 \%)$, UTBM thể nhú $(19,4 \%)$, u tuyến nang $(9,7 \%)$. Kết quả của chúng tôi tương đương của Chu Thị Giang [5] (tỷ lệ ác tính trên mô bệnh học của bướu nhân tuyến giáp là $24,7 \%$ trong đó $100 \%$ các trường hợp là ung thư biểu mô thể nhú, tỷ lệ lành tính là $75,3 \%)$, cao hơn kết quả của Trần Văn Tuấn [8] (tỷ lệ ác tính là 14,9\%, lành tính là $85,1 \%$ ). Điêu này có thể là trong nhóm nghiên cứu bệnh nhân được phẫu thuật không mang tính ngẫu nhiên mà có tính định hướng như nghi ngờ ác tính hoặc ác tính... do vậy làm tỷ lệ dương tính của chúng tôi cao hơn.

Đối chiếu tính chất phản âm của nhân giáp trên siêu âm với chẩn đoán mô bệnh học trong bảng 3.7 cho thấy: trong nhóm lành tính các bướu nhân chủ yếu là hỗn hợp âm $(60 \%)$, giảm âm $(20 \%)$, tăng âm $(16 \%)$ và đồng âm là $4 \%$. Trong nhóm ác tính, 66,6\% các trường hợp là giảm âm, không có trường hợp nào là đồng âm. Kết quả nghiên cứu của chúng tôi cũng tương đồng với các nghiên cứu trước đây. Nghiên cứu của Nguyễn Khoa Diệu Vân (2015) cho thây trong nhóm lành tính về mặt tế bào học, tỷ lệ giảm âm là 45,7\%, nhân hỗn hợp chiếm $34,1 \%$, nhân trống âm $12,5 \%$, nhân tăng âm $5,4 \%$ và nhân đồng âm 2,3\%. Trong nhóm ác tính, 100\% là nhân đặc giảm âm [9].

Bảng 3.8 cho thây có $76 \%$ trường hợp chẩn đoán mô bệnh học lành tính không có dấu hiệu vôi hóa, $12 \%$ có vôi hóa thô hoặc vi vôi hóa. Trong nhóm ác tính, 66,7\% trường hợp có vi vôi hóa và $33,3 \%$ không có vôi hóa, không có trường hợp nào vôi hóa thô. Sự khác biệt có ý nghĩ thống kê với $p<0,05$. Kết quả nghiên cứu của Nguyễn Khoa Diệu Vân cho thấy: trong nhóm ác tính, tỷ lệ vì vôi hóa là $72,7 \%$, còn trong nhóm lành tính là $6,2 \%$, sự khác biệt có ý nghĩa thống kê với $p<0,05$ [9]. Theo Nguyễn Thi Hoa Hồng, đặc điểm vôi hóa gặp chủ yếu ở nhóm ác tính (67,8\%), trong đó vi vôi hóa chiếm tỷ lệ cao nhất $57,1 \%$, còn lại là vôi hóa lớn hoặc không vôi hóa, không gặp trường hợp nào vôi hóa viền trong nhóm ác tính. Các nhân lành tính không có vôi hóa chiếm tỷ lệ cao $(87,9 \%)$, chỉ có $12,1 \%$ nhân có vôi hóa, trong đó vi vôi hóa chỉ chiếm $3,4 \%$, vôi hóa thô là $4,3 \%$ và vôi hóa viền là 3,4\% [6]. Dấu hiệu vi vôi hóa là đặc điểm siêu âm có liên quan nhiều đến các nhân ác tính, do vậy khi khảo sát các nhân tuyến giáp cần chú ý đến đặc điểm này. Vì vậy, hiện nay siêu âm không chỉ là phương tiện chẩn đoán bệnh, mà các đặc điểm của siêu âm còn giúp các thầy thuốc lâm sàng tiên lượng nguy cơ ác tính của một bướu nhân và đưa ra phương pháp điều trị thích hợp.

\section{KẾT LUẬN}

- Kích thước trung bình của các nhân u được chọc hút là 10,5 $\pm 7,2 \mathrm{~mm}$.

- Bờ và giới hạn: các bướu nhân có bờ đều, ranh giới rõ chiếm tỷ lệ cao $(85,2 \%)$, bờ không đều chiếm tỷ lệ thấp.

- Tính chất phản âm: đa số các nhân giáp là hỗn hợp âm $(51,7 \%)$, sau đó là giảm âm $(32,4 \%)$, các nhân tăng âm hoặc đồng âm chiếm tỷ lệ thấp.

- Dấu hiệu vôi hóa: các nhân giáp không có hiện tượng vôi hóa chiếm tỷ lệ cao $(68,8 \%)$, các nhân có vi vôi hóa chiếm tỳ lệ thấp $(9,0 \%)$.

- Kết quả chẩn đoán tế bào học: bướu nhân lành tính $(95,4 \%)$, ung thư biểu mô tuyến giáp thể nhú $3,4 \%$, nghi ngờ $(1,2 \%)$. 
- Kết quả chẩn đoán mô bệnh học: bướu giáp keo lành chiếm tỷ lệ $70,9 \%$, UTBM thể nhú $19,4 \%$, u tuyến nang $9,7 \%$. Các nhân giáp ác tính có kích thước nhỏ $<10 \mathrm{~mm}(66,7 \%)$, là nhân giảm âm $(66,6 \%)$ và có vi vôi hóa $(66,7 \%)$.

\section{TÀI LIỆ THAM KHẢO}

1. Ngưyễn Thị Thắng, Trân Đình Ngạn (2003), "Đánh giá vai trò cúa siêu âm và chọc hút tế bào kim nhỏ trong chẩn đoán bướu nhân tuyến giáp", Tap chí y hoc, 38, 39.

2. Martin Schlumberger, Furio Pacini (2006). Thyroid Tumors. 3th edition. 11 - 63, 111 - 127.

3. Mazzaferri EL (1993). Management of a solitary thyroid nodule. N Engl J Med, 328, 553-559.

4. Nguyến Thị Hồng (2016), Xác định giá trị của phương pháp tế bào học và sinh thiết tức thì trong chẩn đoán ung thư tuyến giáp, Luận văn thạc sĩ y học, Đại học Y Hà Nội.
5. Chu Thị Giang (2018), Nghiên cứu đặc điểm lâm sàng, cận lâm sàng và kết quả chọc hút bướu nhân tuyến giáp tai Bênh viên đa khoa tỉnh Ninh Bình, Luận văn tốt nghieêp bác sỹ chuyên khoa II, Đại họ Y Y Dược Thái Bình.

6. Nguyền Thị Hoa Hồng (2012), Nghiên cứu đặc điểm lâm sàng, siêu âm, choc tể bào kim nhỏ và sinh thiết tức thì trong chẩn đoán bướu nhân tuyến giáp, Luận văn tốt nghiệp bác sỹ nội trú, Đại hoc $Y$ Hà Nôi.

7. Nguyễn Thị Minh Thức (2012). Nghiên cứu đăc điểm di căn hach trong ung thư biểu mố tuyển giáp biệt hóa. Luâan văn tốt nghiệp bác sỹ nội trú. Trường Đại học Y Y Hà Nội.

8. Trân Văn Tuấn, Nguyễn Đình Tùng (2010), "Khảo sát hình ảnh siêu âm và chọc hút tế bào kim nhỏ dưới hướng dẫn siêu âm các khối bất thường tuyến giáp tại Bệnh viện trung ương Huế", Tạp chí Y Hoc TP. Hồ Chí Minh * Tập $14 *$ Phụ bản của Số 4 * 2010.

9. Nguyến Khoa Diệu Vân (2013), "Nội tiết học trong thực hành lâm sàng", NXB Y hoc, trang 110-118.

\section{ĐĂC ĐIỂM HÌNH ẢNH SIÊU ÂM CỦA HACH Cổ DI CĂN Ở BỂNH NHÂN UNG THƯ TUYẾN GIÁP THỂ BIỆT HÓA SAU PHẪU THUÂTT VÀ ĐIỀU TRI 131I}

\section{Phan Hồng Quân ${ }^{1}$, Tưởng Thị Hồng Hạnh², Nguyễn Kim Lưư ${ }^{3}$ Ngô Thị Minh Hạnh² \\ TÓM TẮT \\ Mục đích: Mục đích của nghiên cứu là đánh giá các đặc điểm siêu âm của hạch cổ di căn ở bệnh nhân ung thư tuyến giáp thể biệt hóa sau phẫu thuật và điều trị ${ }^{131} \mathrm{I}$. Đối tượng và phương pháp nghiên cứu: Nghiên cứu hồi cứu kết hợp tiến cứu, mô tả cắt \\ SUMMARY \\ ULTRASOUND IMAGING FEATURES OF CERVICAL LYMPH NODES METASTASIS IN PATIENTS WITH PAPILLARY THYROID CANCER AFTER SURGERY AND TREATMENT WITH ${ }^{131}$ I} ngang 61 bệnh nhân với 123 hạch cổ. Bệnh nhân được phẫu thuật vét hạch làm mổ bệnh học tại Bệnh viện Trung ương Quân đội 108 trong thời gian từ tháng 10/2020 đến tháng 4/2021. Kết quả: Chúng tôi đã tiến hành siêu âm ở 123 hạch vùng cổ. Đối chiếu với kết quả giải phẫu bệnh, có 73 hach di căn, 50 hach không di căn. Hình dang tròn, mất rốn hach, hồi âm, vôi hóa và mạch máu bất thường gặp ở hạch di căn hơn so với hach không di căn, trong khi ranh giới và kích thước không khác biệt đáng kể. Kết luận: Nghiên cứu của chúng tôi cho thây rằng các đăc điểm trên siêu âm về hình dạng tròn, hồi âm, vôi hóa, mất rốn hạch và tăng sinh mạch bất thường là những tiêu chuẩn siêu âm hữu ích để phân biệt giữa các hạch cổ di căn và không có di căn trên bệnh nhân ung thư tuyến giáp thể biệt hóa đã phẫu thuật và điều trị ${ }^{131} \mathrm{I}$.

Tư khóa: siêu âm B-mode, siêu âm Doppler màu, mô bệnh học, di căn hạch.

${ }^{1}$ Học viện Quân y

²Bệnh viện Trung ương Quân đội 108

33eệnh viện Quân y 103

Chịu trách nhiệm chính: Phan Hồng Quân

Email: phanhongquannd@gmail.com

Ngày nhận bài: 10.8.2021

Ngày phản biên khoa họ: 5.10 .2021

Ngày duyệt bài: 14.10.2021
Background: The purpose of the study was to evaluate the characters of B Mode and color Doppler ultrasound (CDUS) in diagnosis cervical lymph nodes metastasis in patients with papillary thyroid after surgery and treatment with ${ }^{131} \mathrm{I}$. Materials and Methods: Retrospective combined with prospective research, cross-sectional description of 61 patients with 123 lymph nodes, surgical and histopathological in 108 Military Central Hospital during the period from October 2020 to April 2021. Results: We conducted ultrasound in 123 lymph nodes. To compare with the pathology results of the disease, there are 73 metastatic lymph nodes, 50 nonmetastatic lymph nodes. Round shape, loss of an echogenic fatty hilum, echo, calcification, and abnormal vascularity were significantly more common in metastatic than nonmetastatic lymph nodes, whereas the boundary and size did not significantly differ. Conclusions: Our study found that the ultrasuond features of round shape, echo, calcification, loss of echogenic fatty hilum, and abnormal vascularity were useful sonographic criteria for differentiating between cervical lymph nodes with and without metastasis in patients with papillary thyroid after surgery and treatment with ${ }^{131} \mathrm{I}$.

Keywords: B-mode ultrasound, Doppler color ultrasonography, histopathology, metastatic lymph node. 